\title{
Quality Improvement Design on Sales Website Using Fuzzy Quality Function Deployment (FQFD) Method
}

\author{
Anindita Dewi Artanti, Yati Rohayati, and Fakhirah Nur Alifah \\ School of Industrial Engineering, Institut Teknologi Sepuluh Nopember, Surabaya \\ e-mail: aninditadartanti@student.telkomuniversity.ac.id
}

\begin{abstract}
PT. XYZ is a company engaged in fashion which manufactures and sells its own products to consumers. The company sells through various online media including its own website and several marketplace media. However, their consumers make more online purchases through the marketplace than the website, which makes it difficult because the company can only use purchases from the website to obtain complete customer data needed to explore customer behavior. This research will be done using the Fuzzy QFD method to improve the quality of online sales service through the website based on the identified weaknesses of the company website that causes consumers to avoid making online purchases through the website. Fuzzy QFD is a QFD method integrated with fuzzy logic which aims to reduce the vagueness or obscurity of subjective judgments to improve calculation accuracy. The results of this research are 5 technical requirement from FQFD 1st iteration and critical part from 2nd iteration which are expected to produce recommendations needed by company to improve the quality of online sales services through its website based on a more objective and accurate data.
\end{abstract}

Keywords - Fuzzy QFD, Online Sales, Website.

\section{INTRODUCTION}

$\mathrm{D}^{\prime}$ IGITAL marketing is a communication tool used in marketing products using technology in the form of online marketing, internet marketing, or web marketing (Deekshith \& Kinslin, 2016). The use of technology in marketing company products, in addition to selling, is also used to facilitate customer data collection and storage.

Customer data is needed so that companies can continue to provide the latest information to consumers about products produced by the company or about the company itself. This is usually done in order to keep consumers loyal to the products produced by the company or to always maintain the relationship between the company and customers.

One company that has problems in collecting customer data is PT. XYZ. PT. XYZ is a company located in the city of Bandung, which sells various models of bags produced directly by this company with the main target of consumers being teenagers. This problem was found, after an assessment of the website at PT. XYZ with one of the company owners. The results of the study show that many consumers prefer to buy products through marketplaces such as Line, Shopee, Tokopedia, Bukalapak, and others compared to PT. XYZ as shown in Figure 1.

Figure 1 shows the sales revenue made through the website of PT. XYZ is only $10.52 \%$ compared to total sales. The income illustrates the small consumer purchases on the

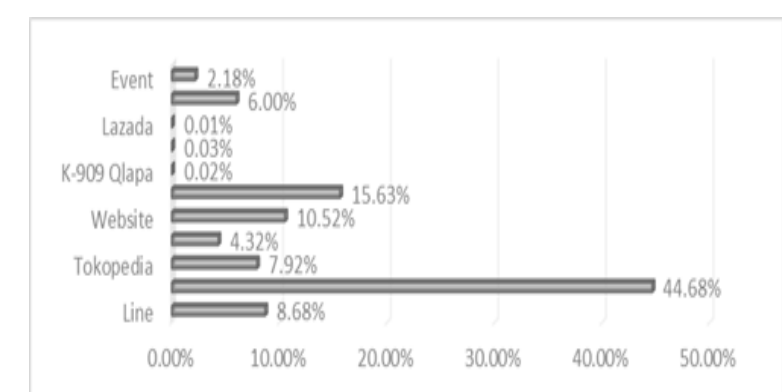

Figure 1. Sales Data for November 2018 - October 2019.

website of PT. XYZ, of the sales target desired by the company, which is $60 \%$ of sales come from the website of PT. XYZ. Therefore, PT. XYZ began to develop on their sales website, after realizing that customer data in the company's development was needed. Meanwhile, customer data is obtained after consumers make purchases through the website of PT. XYZ

In terms of knowing the least amount of product purchases on the sales website of PT. XYZ, the consumer's view of the PT. XYZ is very necessary. For this reason, a preliminary survey of 9 consumers who had opened the PT. XYZ. This preliminary survey, conducted through in-depth interviews (in-depth interviews) to determine consumer ratings of the website of PT. XYZ. Table 1 shows complaints of preliminary survey results and comparison of $\mathrm{PT}$. XYZ and PT. ABC as a competitor of PT. XYZ, based on existing complaints.

Based on Table 1 it can be seen that complaints from PT. XYZ when accessing the website of PT. XYZ. This is what makes customers tend to buy products not through the website. Therefore, companies need to design a better quality website.

\section{METHOD}

\section{A. Quality Function Deployment}

Quality function deployment or QFD is a concept that was first introduced by Yoji Akao and Shigeru Mizuno (Alsaadi et al., 2018). The QFD concept is a methodology developed to translate Voice of Customer ( $\mathrm{VoC})$ into technical characteristics used in the design of products or services (Iqbal et al., 2015). Quality function deployment is very important in developing a product/service, because the QFD concept provides steps in understanding the needs and demands of consumers for a product or service which is then translated into the form of technical characteristics that have 
Table 1.

Comparison of PT. XYZ with PT. ABC based on complaints

\begin{tabular}{|c|c|c|}
\hline Complaint & PT. XYZ & PT. ABC \\
\hline $\begin{array}{l}\text { Website } \\
\text { display }\end{array}$ & $\begin{array}{l}\text { Inefficient use of } \\
\text { layouts }\end{array}$ & Use efficient layouts \\
\hline Navigation & $\begin{array}{l}\text { There are inefficient } \\
\text { features, so it } \\
\text { requires more clicks } \\
\text { for a process }\end{array}$ & $\begin{array}{l}\text { There are efficient } \\
\text { features, so they } \\
\text { require a smaller } \\
\text { number of clicks for a } \\
\text { process }\end{array}$ \\
\hline $\begin{array}{l}\text { Graphic } \\
\text { design on the } \\
\text { menu display }\end{array}$ & $\begin{array}{l}\text { - There are no } \\
\text { barriers between } \\
\text { menus and } \\
\text { submenus, the } \\
\text { distance between the } \\
\text { posts in the remote } \\
\text { submenu and the } \\
\text { search feature } \\
\text { cannot be clearly } \\
\text { seen } \\
\text {-There are } \\
\text { navigation features } \\
\text { in the form of } \\
\text { overlapping icons }\end{array}$ & $\begin{array}{l}\text { - There is a border } \\
\text { between the menu and } \\
\text { submenus, the } \\
\text { distance between the } \\
\text { posts in the submenu } \\
\text { is sufficient and the } \\
\text { search feature can be } \\
\text { seen clearly } \\
\text { - There is no } \\
\text { navigation feature in } \\
\text { the form of } \\
\text { overlapping icons }\end{array}$ \\
\hline Loading time & 2 to 3 seconds & 0 to 1 second \\
\hline $\begin{array}{l}\text { Product } \\
\text { information }\end{array}$ & $\begin{array}{l}\text { Less specific } \\
\text { explanation about } \\
\text { the product }\end{array}$ & $\begin{array}{l}\text { A more specific } \\
\text { description of the } \\
\text { product }\end{array}$ \\
\hline
\end{tabular}

Table 2.

Nilai Pengali Kategori Kano

\begin{tabular}{cc}
\hline \hline Kano Category & Kano Multiplier Value \\
\hline A (Attractive) & 4 \\
O (One Dimensional) & 2 \\
M (Must Be) & 1 \\
\hline
\end{tabular}

Table 3.

Converting Scale of Relationship between Technical Characteristics and True Customer Need to Triangular Fuzzy Number

\begin{tabular}{lc}
\hline \multicolumn{1}{c}{ Relationship } & TFN \\
\hline Strong relationship & $(4,9,9)$ \\
Medium relationship & $(1,3,5)$ \\
Weak relationship & $(0,1,2)$ \\
No relation & $(0,0,1)$ \\
\hline \hline
\end{tabular}

benefits in achieving the highest level of customer satisfaction (Asadabadi, 2016). The development of concepts using QFD can not only be done by manufacturers but also in the fields of planning, design, and processes at each stage of the product (Iqbal et al., 2015). From the above statement, it can be seen that QFD is a method that can be used in developing products/services through the translation of consumer needs to product planning, product design until product sales process.

\section{B. Fuzzy Logic}

A tool used in analyzing uncertainty into a strong decision is fuzzy logic (Zadeh, 2015). Fuzzy value operation can be done in several ways below (Pandiya, Wahyudin, \& Nareswari, 2016).

$$
\begin{array}{ll}
\text { Addition } & \rightarrow \mathrm{N} 1+\mathrm{N} 2=(\mathrm{a} 1+\mathrm{a} 2, \mathrm{~b} 1+\mathrm{b} 2, \mathrm{c} 1+\mathrm{c} 2) \\
\text { Multiplication } & \rightarrow \mathrm{N} 1 \times \mathrm{N} 2=(\mathrm{a} 1 \times \mathrm{a} 2, \mathrm{~b} 1 \times \mathrm{b} 2, \mathrm{c} 1 \times \mathrm{c} 2) \\
\text { Division } & \rightarrow \mathrm{N} 1 / \mathrm{N} 2=(\mathrm{a} 1 / \mathrm{a} 2, \mathrm{~b} 1 / \mathrm{b} 2, \mathrm{c} 1 / \mathrm{c} 2)
\end{array}
$$

Multiplication with non-fuzzy numbers $\rightarrow \mathrm{r}$ x N2 $=(\mathrm{ra}, \mathrm{rb}$, rc)

$$
\begin{aligned}
\text { Where : } \mathrm{N} & =\text { Traditional Number } \\
(\mathrm{a}, \mathrm{b}, \mathrm{c}) & =\text { Triangular Fuzzy Number from } \mathrm{N}
\end{aligned}
$$

In using fuzzy values in the calculation process, there is the term crisp number. Crisp numbers are the final numbers

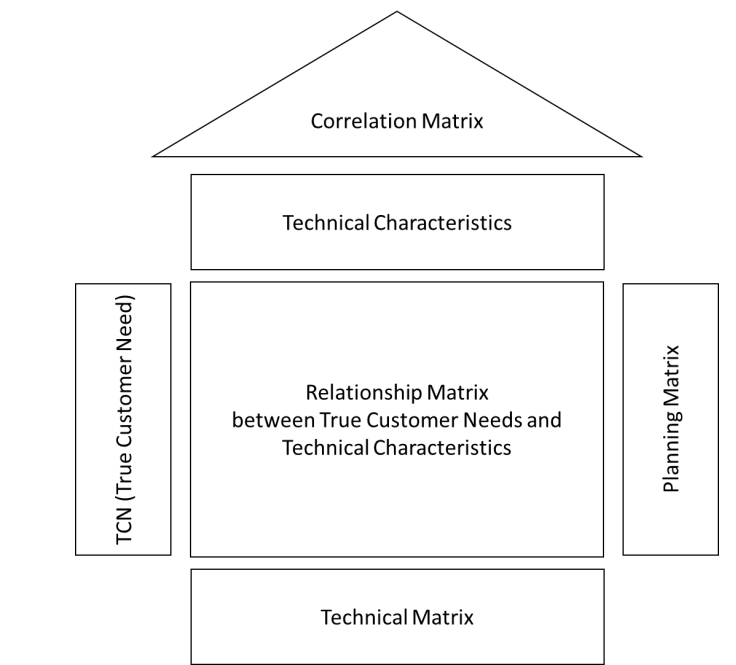

Figure 2. HOQ Matrix.

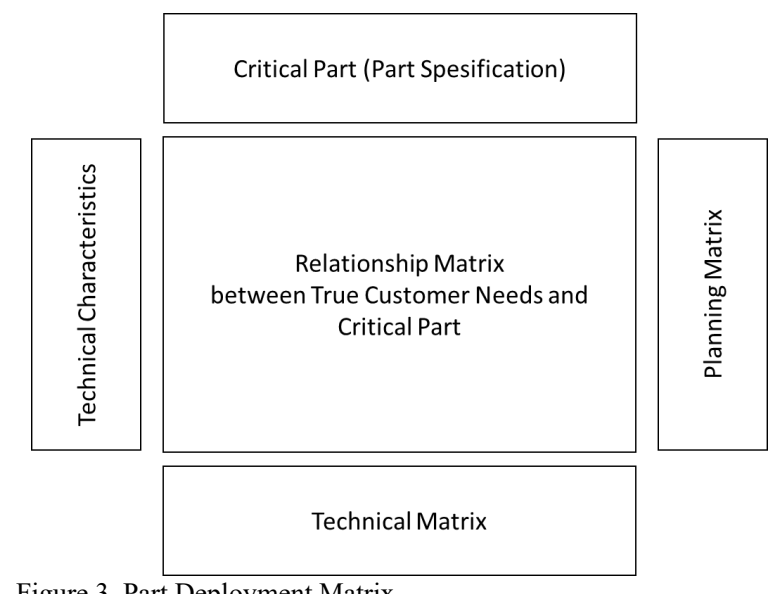

Figure 3. Part Deployment Matrix.

from the results of using fuzzy values in a process, these numbers are obtained after a defuzzification process (Pandiya et al., 2016). The following is a calculation in the defuzzification process.

$\mathrm{M}(\mathrm{a}, \mathrm{b}, \mathrm{d})$

Where, $M(a, b, c)$

$=(\mathrm{a}+4 \mathrm{~b}+\mathrm{c}) / 6$

$(a, b, c)$

$=$ Crisp Number

= Fuzzy Number

\section{Fuzzy Quality Function Deployment}

Fuzzy number is then integrated with QFD to reduce inappropriate and vague decision making because it uses subjective values (Mohanraj \& Sakthivel, 2014). This integration produces fuzzy QFD, which is a method used in translating a technical product from the needs of consumers in a product and produces a ranking of the value of the product's technical relationship and consumer needs, which are assessed subjectively, for more appropriate decisionsolving.

\section{1) Fuzzy Quality Function Deployment Iterasi 1}

Fuzzy QFD iteration 1 uses the House of Quality matrix tool. This matrix is divided into six parts namely, the consumer needs matrix (true customer needs), the technical characteristics matrix, planning matrix, the relationship matrix between true customer needs and technical characteristics, the correlation matrix between technical 
Table 4.

Scale that Determines Correlation Level between Technical Characteristics

\begin{tabular}{lc}
\hline \hline \multicolumn{1}{c}{ Relationship Symbols } & Relationship Symbols \\
\hline Very positively related & $\bullet$ \\
Positively related & $\circ$ \\
Negatively related & $\vdots$ \\
Very negatively related & $\bullet$ \\
\hline \hline
\end{tabular}

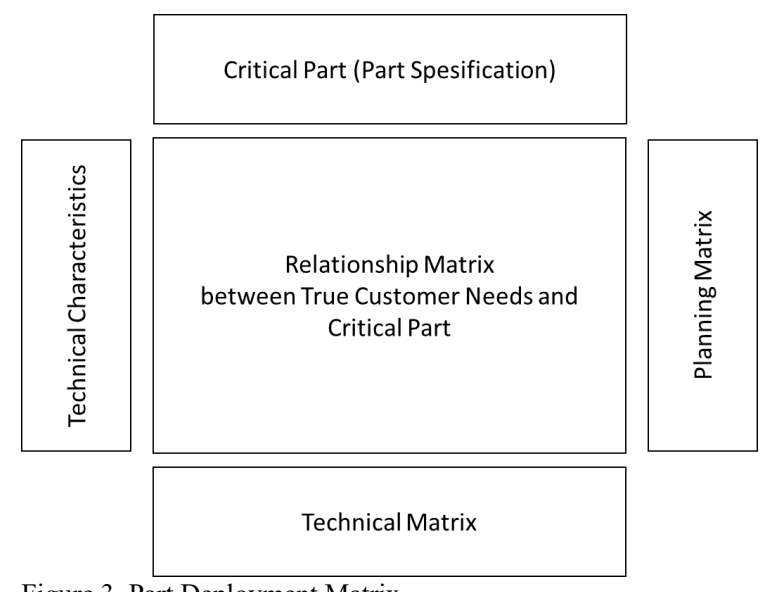

Figure 3. Part Deployment Matrix.

characteristics and the technical matrix. Figure 2 is an illustration of the HOQ matrix.

The planning matrix is filled with the results of multiplying the Fuzzy NKP value with the Kano multiplier value. Kano multiplier values were obtained from the kano category as described in Table 2 (Rahman et al, 2014). The technical matrix contains the value of existing companies, competitors and company targets, units, and the results of fuzzy value processing in the relationship matrix and planning matrix.

The value that is filled in the matrix of the relationship between true customer needs and technical characteristics by the internal parties of the company is first translated into fuzzy values before proceeding with data processing. Data processing results in a ranking of true customer needs. Conversion values are explained in the table below (Nawar, Backar, \& El-Dardiry, 2018).

The filling out of the relationship between technical characteristics was also carried out by the internal developer of the PT. XYZ website. The scale used in determining the relationship between technical characteristics is stated in Table 4 (Erdil \& Arani, 2018).

2) Concept Development

Concept development is the stage for designing and selecting concepts based on the characteristics that have been obtained in FQFD iteration 1. The results of the development of this concept are then continued to FQFD iteration 2 (Part Deployment). The concept development stage begins with designing the concept and then continues with the concept selection stage after making several considerations of the alternative concepts formed.

3) Fuzzy Quality Function Deployment iteration 2

Fuzzy QFD iteration two (part deployment) is data processing with the same steps as Fuzzy QFD iteration 1. Beginning with the determination of the value of column weight percentage, then determining the critical part, the relationship between critical parts with technical
Table 5.

TCN Data, Fuzzy NKP Values and Kano Categories

\begin{tabular}{|c|c|c|c|c|c|}
\hline Code & $\begin{array}{c}\text { True Customer } \\
\text { Needs }\end{array}$ & & $\begin{array}{l}\mathrm{KP}(\mathrm{Fu} \\
\text { Number }\end{array}$ & & $\begin{array}{c}\text { Kano } \\
\text { Categories }\end{array}$ \\
\hline QC1 & $\begin{array}{l}\text { The ability of the } \\
\text { website } \\
\text { maintain } \\
\text { performance and } \\
\text { improve the } \\
\text { system when an } \\
\text { error occurs }\end{array}$ & 6.88 & 7.87 & 8.36 & $\mathrm{O}$ \\
\hline QC2 & $\begin{array}{l}\text { Ease of website for } \\
\text { users to access }\end{array}$ & 7.22 & 8.20 & 8.47 & $\mathrm{O}$ \\
\hline QC3 & $\begin{array}{l}\text { The ability of the } \\
\text { website to be used } \\
\text { on various } \\
\text { communication } \\
\text { tools that can } \\
\text { access the website }\end{array}$ & 6.82 & 7.80 & 8.26 & $\mathrm{O}$ \\
\hline QC4 & $\begin{array}{l}\text { Ease of website to } \\
\text { be operated by } \\
\text { users without } \\
\text { having to spend a } \\
\text { large effort }\end{array}$ & 6.97 & 7.96 & 8.37 & $\mathrm{O}$ \\
\hline QC5 & $\begin{array}{l}\text { The ability of the } \\
\text { website to operate } \\
\text { at any time }\end{array}$ & 6.94 & 7.92 & 8.34 & $\mathrm{O}$ \\
\hline UE1 & $\begin{array}{l}\text { Ease of website to } \\
\text { be understood by } \\
\text { users }\end{array}$ & 7.17 & 8.17 & 8.50 & $\mathrm{O}$ \\
\hline UE2 & $\begin{array}{l}\text { Website interface } \\
\text { looks good and } \\
\text { attractive }\end{array}$ & 6.92 & 7.90 & 8.30 & $\mathrm{O}$ \\
\hline UE3 & $\begin{array}{l}\text { The ability of a } \\
\text { website to provide } \\
\text { a user-friendly } \\
\text { appearance }\end{array}$ & 6.89 & 7.87 & 8.26 & $\mathrm{O}$ \\
\hline IQ1 & $\begin{array}{l}\text { Website } \\
\text { availability to } \\
\text { display estimated } \\
\text { shipping prices for } \\
\text { products }\end{array}$ & 7.12 & 8.11 & 8.47 & $\mathrm{O}$ \\
\hline IQ2 & $\begin{array}{l}\text { The ability of the } \\
\text { website to provide } \\
\text { product } \\
\text { information and } \\
\text { content that is } \\
\text { clear and } \\
\text { understood by } \\
\text { users }\end{array}$ & 7.41 & 8.39 & 8.63 & $\mathrm{O}$ \\
\hline IQ3 & $\begin{array}{l}\text { The ability of the } \\
\text { website to provide } \\
\text { search results } \\
\text { according to the } \\
\text { user's wishes }\end{array}$ & 7.29 & 8.27 & 8.57 & $\mathrm{O}$ \\
\hline RS1 & $\begin{array}{l}\text { The ability of a } \\
\text { website to load } \\
\text { pages quickly }\end{array}$ & 7.04 & 8.03 & 8.42 & $\mathrm{O}$ \\
\hline EP1 & $\begin{array}{l}\text { The sales website } \\
\text { can display } \\
\text { according to user } \\
\text { needs }\end{array}$ & 6.94 & 7.92 & 8.38 & $\mathrm{O}$ \\
\hline
\end{tabular}

characteristics, and ending with a technical matrix. Figure 3 shows the part deployment matrix.

\section{RESULT AND DISCUSSION}

The first step is to obtain input data obtained based on previous research using the Fuzzy Refined Kano Model. The results obtained are TCN data with fuzzy NKP values and Kano Categories (Rahatesa, 2019). 
Table 6.

Technical Characteristics

\begin{tabular}{clcc}
\hline \hline No & Technical Characteristics & Kode & Direction of Goodness \\
\hline 1 & Website maintenance & K1 & MTB \\
2 & Use of SEO & K2 & LTB \\
3 & Navigation feature & K3 & TB \\
4 & Front end & K5 & MTB \\
5 & Customer service online time & K6 & MTB \\
6 & Display total price & K7 & MTB \\
7 & Product information display & K8 & MTB \\
8 & Display of search results (search column) & K9 & LTB \\
9 & Website loading time & K10 & MTB \\
10 & Search display options & & \\
\hline \hline
\end{tabular}

Table 7.

Adjusted Importance

\begin{tabular}{|c|c|c|c|c|c|c|c|}
\hline \multicolumn{2}{|l|}{$\begin{array}{l}\text { TCN } \\
\text { Code }\end{array}$} & \multicolumn{2}{|c|}{ NKP (Fuzzy Number) } & \multirow{2}{*}{$\begin{array}{c}\text { Kano Multiplier Value } \\
2\end{array}$} & \multicolumn{3}{|c|}{ Adjusted Importance (Fuzzy Number) } \\
\hline QC1 & 6.88 & 7.87 & 8.36 & & 13.76 & 15.74 & 16.71 \\
\hline QC2 & 7.22 & 8.20 & 8.47 & 2 & 14.43 & 16.40 & 16.94 \\
\hline QC3 & 6.82 & 7.80 & 8.26 & 2 & 13.63 & 15.60 & 16.52 \\
\hline QC4 & 6.97 & 7.96 & 8.37 & 2 & 13.95 & 15.91 & 16.75 \\
\hline QC5 & 6.94 & 7.92 & 8.34 & 2 & 13.88 & 15.84 & 16.68 \\
\hline UE1 & 7.17 & 8.17 & 8.50 & 2 & 14.35 & 16.33 & 17.01 \\
\hline UE2 & 6.92 & 7.90 & 8.30 & 2 & 13.84 & 15.81 & 16.61 \\
\hline UE3 & 6.89 & 7.87 & 8.26 & 2 & 13.77 & 15.74 & 16.52 \\
\hline IQ1 & 7.12 & 8.11 & 8.47 & 2 & 14.24 & 16.23 & 16.94 \\
\hline IQ2 & 7.41 & 8.39 & 8.63 & 2 & 14.82 & 16.78 & 17.25 \\
\hline IQ3 & 7.29 & 8.27 & 8.57 & 2 & 14.57 & 16.54 & 17.13 \\
\hline RS1 & 7.04 & 8.03 & 8.42 & 2 & 14.09 & 16.05 & 16.83 \\
\hline EP1 & 6.94 & 7.92 & 8.38 & 2 & 13.88 & 15.84 & 16.77 \\
\hline
\end{tabular}

Table 8.

Planning Matrix

\begin{tabular}{|c|c|c|c|c|c|c|}
\hline $\begin{array}{l}\text { TCN } \\
\text { Code }\end{array}$ & \multicolumn{3}{|c|}{ Fuzzy Priority of Adjusted Importace } & \multirow{2}{*}{$\begin{array}{c}\text { Crisp Value } \\
0.90\end{array}$} & \multirow{2}{*}{$\begin{array}{c}\begin{array}{c}\text { Adjusted Importance } \\
\text { Percentage }\end{array} \\
7.55 \%\end{array}$} & \multirow{2}{*}{$\begin{array}{c}\text { Rank } \\
11\end{array}$} \\
\hline QC1 & 0.80 & 0.91 & 0.97 & & & \\
\hline QC2 & 0.84 & 0.95 & 0.98 & 0.94 & $7.84 \%$ & 3 \\
\hline QC3 & 0.79 & 0.90 & 0.96 & 0.89 & $7.48 \%$ & 13 \\
\hline QC4 & 0.81 & 0.92 & 0.97 & 0.91 & $7.63 \%$ & 7 \\
\hline QC5 & 0.80 & 0.92 & 0.97 & 0.91 & $7.59 \%$ & 9 \\
\hline UE1 & 0.83 & 0.95 & 0.99 & 0.93 & $7.81 \%$ & 4 \\
\hline UE2 & 0.80 & 0.92 & 0.96 & 0.91 & $7.57 \%$ & 10 \\
\hline UE3 & 0.80 & 0.91 & 0.96 & 0.90 & $7.54 \%$ & 12 \\
\hline IQ1 & 0.83 & 0.94 & 0.98 & 0.93 & $7.77 \%$ & 5 \\
\hline IQ2 & 0.86 & 0.97 & 1.00 & 0.96 & $8.02 \%$ & 1 \\
\hline IQ3 & 0.84 & 0.96 & 0.99 & 0.95 & $7.91 \%$ & 2 \\
\hline RS1 & 0.82 & 0.93 & 0.98 & 0.92 & $7.69 \%$ & 6 \\
\hline \multirow[t]{2}{*}{ EP1 } & 0.80 & 0.92 & 0.97 & 0.91 & $7.60 \%$ & 8 \\
\hline & & To & & & $100.00 \%$ & \\
\hline
\end{tabular}

Technical characteristics were obtained from the results of identification on 13 TCN by discussing with internal and external parties the PT. XYZ website developer. TCN is then broken down into 10 technical characteristics as in Table 6 .

The planning matrix contains the value of fuzzy priority of adjusted importance, crisp value of fuzzy priority of adjusted importance, adjusted importance percentage and ranking of each technical characteristic based on adjusted importance value. The fuzzy priority value of adjusted importance is obtained from the fuzzy priority importance value. Fuzzy adjusted importance is derived from the multiplication between the NKP fuzzy value and the kano multiplier value of the kano category on each technical characteristic. Table 7 shows the NKP fuzzy value, the kano category in each technical characteristic, the kano multiplier value derived from the kano category and the calculation results for the data needed on this matrix are fuzzy adjusted importance values.

After obtaining the value of fuzzy adjusted importance, then determine the value of fuzzy priority of adjusted importance. Fuzzy priority value of adjusted importance is obtained from the division of each value of fuzzy adjusted importance with the greatest value in the value of fuzzy adjusted importance. While the adjusted importance percentage value comes from the calculation of crisp value on the fuzzy priority of adjusted importance. The crisp value 


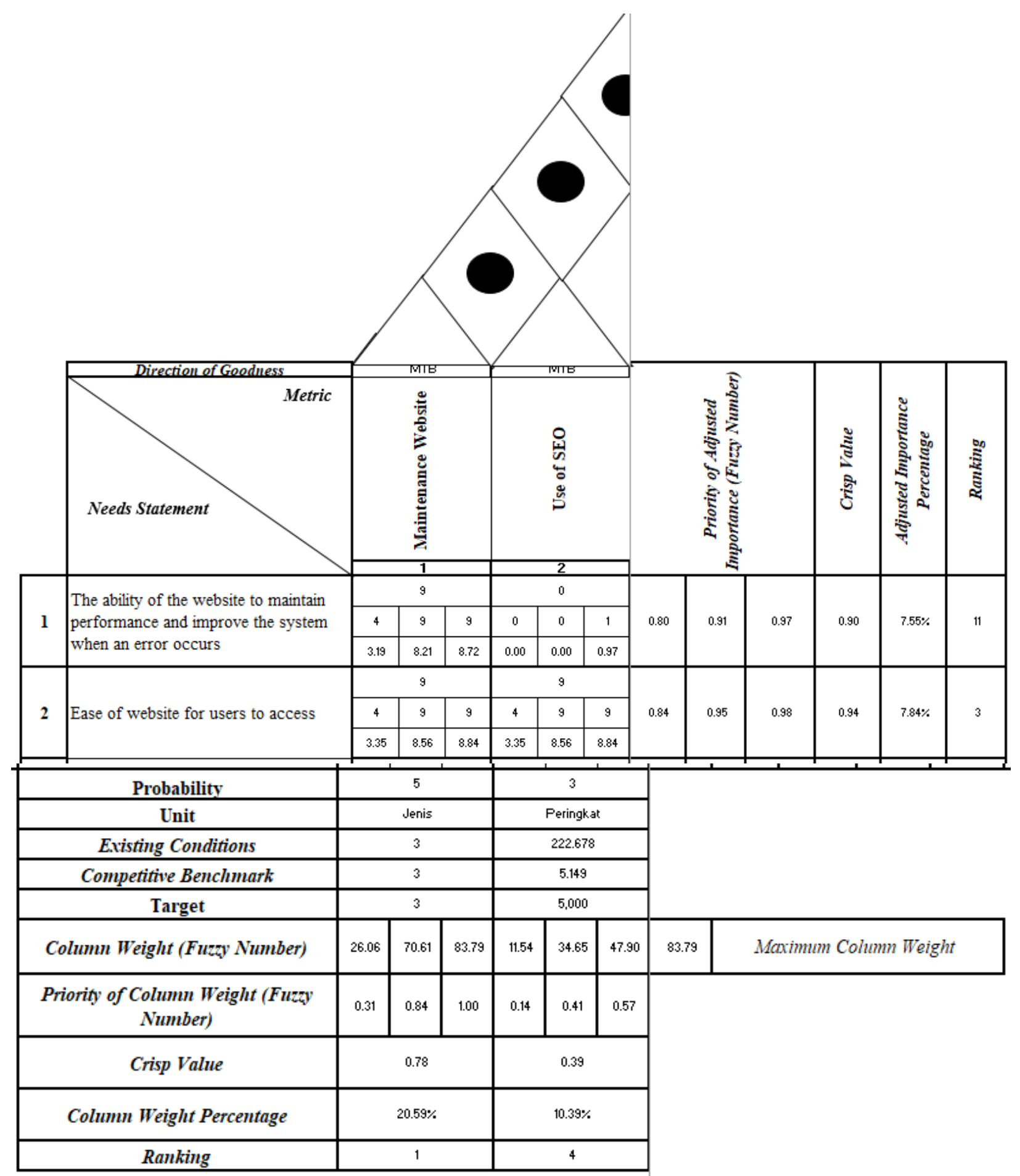

Figure 4. FQFD Iterasi 1.

of the fuzzy priority of adjusted importance is divided by the total of the crisp value of the fuzzy priority of adjusted importance. Then, the value is multiplied by $100 \%$ to get the percentage value used to determine the rank for each true customer needs. The results of the calculation of the value of fuzzy priority of adjusted importance, crisp value of fuzzy priority of adjusted importance and adjusted importance percentage used to determine the ranking of each technical characteristic can be seen in Table 8 .

Furthermore, an analysis using the HoQ matrix can be seen in Figure 4 and, with the results of the identification of ten technical characteristics and five priorities for improvement of technical characteristics based on targets that the company has not yet met. The priority technical characteristics are the use of SEO, navigation features, front end, display of search results (search column), and website loading time.

Probability is determined based on the likelihood of the company meeting the targets of the established technical characteristics. The possibility is indicated by the numbers one to five. With the statement the greater the probability value, the greater the possibility to meet the target technical 
Table 9.

Technical Characteristics Ranking

\begin{tabular}{|c|c|c|c|c|c|c|}
\hline Code & Probability & $\begin{array}{c}\text { Fuzzy Column } \\
\text { Weight }\end{array}$ & $\begin{array}{l}\text { Fuzzy Priority of } \\
\text { Column Weight }\end{array}$ & Crisp Value & $\begin{array}{c}\text { Column Weight } \\
\text { Percentage }\end{array}$ & Rank \\
\hline & & 26.06 & 0.31 & & & \\
\hline \multirow[t]{3}{*}{$\mathrm{K} 1$} & 5 & 70.61 & 0.84 & 0.78 & $20.59 \%$ & 1 \\
\hline & & 83.79 & 1.00 & & & \\
\hline & & 11.54 & 0.14 & & & \\
\hline \multirow[t]{3}{*}{$\mathrm{K} 2$} & 3 & 34.65 & 0.41 & 0.39 & $10.39 \%$ & 4 \\
\hline & & 47.90 & 0.57 & & & \\
\hline & & 13.78 & 0.16 & & & \\
\hline \multirow[t]{3}{*}{$\mathrm{K} 3$} & 3 & 43.53 & 0.52 & 0.50 & $13.28 \%$ & 3 \\
\hline & & 65.20 & 0.78 & & & \\
\hline & & 21.95 & 0.26 & & & \\
\hline \multirow[t]{3}{*}{ K4 } & 3 & 61.24 & 0.73 & 0.68 & $17.88 \%$ & 2 \\
\hline & & 73.92 & 0.88 & & & \\
\hline & & 0.83 & 0.01 & & & \\
\hline \multirow[t]{3}{*}{ K5 } & 5 & 7.45 & 0.09 & 0.10 & $2.73 \%$ & 10 \\
\hline & & 21.46 & 0.26 & & & \\
\hline & & 4.99 & 0.06 & & & \\
\hline \multirow{3}{*}{ K6 } & 5 & 17.91 & 0.21 & 0.22 & $5.72 \%$ & 8 \\
\hline & & 32.33 & 0.39 & & & \\
\hline & & 6.69 & 0.08 & & & \\
\hline \multirow[t]{3}{*}{ K7 } & 5 & 20.81 & 0.25 & 0.25 & $6.67 \%$ & 7 \\
\hline & & 37.20 & 0.44 & & & \\
\hline & & 3.28 & 0.04 & & & \\
\hline \multirow[t]{3}{*}{ K8 } & 3 & 15.90 & 0.19 & 0.20 & $5.25 \%$ & 9 \\
\hline & & 33.19 & 0.40 & & & \\
\hline & & 9.70 & 0.12 & & & \\
\hline \multirow[t]{2}{*}{ K9 } & 2 & 28.55 & 0.34 & 0.34 & $8.84 \%$ & 5 \\
\hline & & 44.62 & 0.53 & & & \\
\hline K10 & 4 & 9.07 & 0.11 & 0.33 & $8.64 \%$ & 6 \\
\hline
\end{tabular}

Table 10.

HOQ Matrix (Technical Matrix)

\begin{tabular}{cllc}
\hline \hline No & \multicolumn{1}{c}{ Technical Characteristics } & Unit & Eksisting \\
\hline 1 & Website maintenance & Type & 3 \\
2 & Use of SEO & Ranking & 222.678 \\
3 & Navigation feature & Element & 12 \\
4 & Front end & Element & 7 \\
5 & Customer service online time & Hour & 24 \\
6 & Display total price & Element & 18 \\
7 & Product information display & Information & 8 \\
8 & Display of search results (search column) & Element & 7 \\
9 & Website loading time & Second & 4 \\
10 & Search display options & Element & 7 \\
\hline \hline
\end{tabular}

Table 11.

Reference and Alternative Concepts

\begin{tabular}{|c|c|c|c|}
\hline Technical Characteristics & Existing Concept & "Benchmarking Concept & Development and Innovation Concept \\
\hline Use of SEO & $\begin{array}{l}\text { Do not use articles, meta } \\
\text { description, and meta keywords }\end{array}$ & $\begin{array}{l}\text { Using articles, meta } \\
\text { description } \quad \text { and } \\
\text { keywords }\end{array}$ & $\begin{array}{l}\text { Optimizing the use of articles, meta } \\
\text { description and meta keywords }\end{array}$ \\
\hline Navigation feature & Do not use the dropdown menu & Use the dropdown menu & Optimizes the use of dropdown menus \\
\hline Front end & $\begin{array}{l}\text { Inefficient use of layouts for the } \\
\text { feature placement }\end{array}$ & $\begin{array}{l}\text { Use efficient layouts and use } \\
\text { bright colors }\end{array}$ & $\begin{array}{l}\text { Optimizes the use of layouts and soft } \\
\text { color combinations }\end{array}$ \\
\hline $\begin{array}{l}\text { Display of search results } \\
\text { (search column) }\end{array}$ & $\begin{array}{l}\text { Search is only able to search } \\
\text { according to the correct writing } \\
\text { and only displays articles }\end{array}$ & $\begin{array}{l}\text { Search is only able to search } \\
\text { according to the correct } \\
\text { writing and provide } \\
\text { recommendations }\end{array}$ & $\begin{array}{l}\text { Add search autocorrect to provide } \\
\text { product recommendations and articles } \\
\text { and optimize the use of search } \\
\text { recommendations }\end{array}$ \\
\hline Website loading time & $\begin{array}{l}\text { Website loading time is } 2 \\
\text { seconds but there is an animated } \\
\text { image }\end{array}$ & $\begin{array}{l}\text { Website loading time for } 1 \\
\text { second by reducing image } \\
\text { animation }\end{array}$ & $\begin{array}{l}\text { The use of image optimization system to } \\
\text { reduce website loading time and slightly } \\
\text { reduce image animation }\end{array}$ \\
\hline
\end{tabular}

characteristics, and vice versa. Column weight percentage is obtained in several stages, starting from determining the value of fuzzy column weight by adding up the value of the multiplication weight between the relationship matrix value and the value of the fuzzy adjusted importance percentage in the same technical characteristic. Then proceed to divide each of these results with the largest value obtained in the value of fuzzy column weight to get the value of fuzzy priority of column weight. Next, the calculation of crisp value is performed using the crisp value formula. From this crisp value, a percentage is searched by multiplying the quotient value with the total crisp value by $100 \%$ to get the column weight percentage value. Column weight percentage calculation is performed to determine the priority of technical characteristics. The greater the weight generated, the characteristics will be prioritized. 
Table 12.

Decision Matrix

\begin{tabular}{|c|c|c|c|}
\hline $\begin{array}{l}\text { Selection } \\
\text { Criteria }\end{array}$ & \multicolumn{2}{|c|}{$\begin{array}{c}\text { Benchmarking } \\
\text { concept }\end{array}$} & $\begin{array}{c}\text { Concept of } \\
\text { Development } \\
\text { and } \\
\text { Innovation } \\
\end{array}$ \\
\hline Effectiveness & \multicolumn{2}{|l|}{+} & + \\
\hline Efficiency & 0 & 0 & + \\
\hline Appropriateness & \multicolumn{2}{|l|}{+} & + \\
\hline $\begin{array}{l}\text { Ease to be } \\
\text { realized }\end{array}$ & \multicolumn{2}{|l|}{-} & + \\
\hline $\begin{array}{l}\text { Estimated cost } \\
\text { requirements }\end{array}$ & 0 & 0 & 0 \\
\hline Amount $(+)$ & \multicolumn{2}{|l|}{2} & 5 \\
\hline Amount (0) & \multicolumn{2}{|l|}{2} & 0 \\
\hline Amount (-) & \multicolumn{2}{|l|}{1} & 1 \\
\hline Total & \multicolumn{2}{|l|}{1} & 4 \\
\hline Ranking & \multicolumn{2}{|l|}{2} & 1 \\
\hline Next? & \multicolumn{2}{|c|}{ No } & Yes \\
\hline \multicolumn{4}{|c|}{$\begin{array}{c}\text { Table } 13 . \\
\text { Critical Part }\end{array}$} \\
\hline $\begin{array}{c}\text { Technical } \\
\text { Characteristics }\end{array}$ & Critical Part & Code & $\begin{array}{c}\text { Direction } \\
\text { of } \\
\text { Goodness } \\
\end{array}$ \\
\hline \multirow[t]{3}{*}{ Use of SEO } & \multicolumn{2}{|l|}{ SEO article } & MTB \\
\hline & Meta description & $\mathrm{C} 2$ & МТB \\
\hline & Meta keywords & $\mathrm{C} 3$ & MTB \\
\hline \multirow[t]{4}{*}{$\begin{array}{c}\text { Navigation } \\
\text { feature }\end{array}$} & $\begin{array}{l}\text { Number of clicks on } \\
\text { the product } \\
\text { selection process }\end{array}$ & $\mathrm{C} 4$ & LTB \\
\hline & $\begin{array}{l}\text { Number of clicks on } \\
\text { the payment process }\end{array}$ & $\mathrm{C} 5$ & LTB \\
\hline & $\begin{array}{l}\text { Number of clicks in } \\
\text { the account creation } \\
\text { process }\end{array}$ & C6 & LTB \\
\hline & $\begin{array}{l}\text { Number of sticky } \\
\text { menu icons }\end{array}$ & $\mathrm{C} 7$ & LTB \\
\hline \multirow[t]{4}{*}{ Front end } & $\begin{array}{l}\text { The number of } \\
\text { layouts on the home } \\
\text { menu }\end{array}$ & $\mathrm{C} 8$ & TB \\
\hline & $\begin{array}{l}\text { The number of } \\
\text { layouts in the } \\
\text { product selection } \\
\text { display }\end{array}$ & C9 & TB \\
\hline & $\begin{array}{l}\text { The number of } \\
\text { layouts in the } \\
\text { account creation } \\
\text { view }\end{array}$ & $\mathrm{C} 10$ & TB \\
\hline & $\begin{array}{l}\text { Number of sticky } \\
\text { menu icons }\end{array}$ & $\mathrm{C} 7$ & LTB \\
\hline \multirow{4}{*}{$\begin{array}{c}\text { Display of } \\
\text { search results } \\
\text { (search column) } \\
\text { Website loading } \\
\text { time }\end{array}$} & \multirow{4}{*}{$\begin{array}{l}\text { Search } \\
\text { recommendation } \\
\text { Search autocorrect } \\
\text { Animated image } \\
\text { Picture on the home } \\
\text { menu }\end{array}$} & $\mathrm{C} 11$ & MTB \\
\hline & & $\mathrm{C} 12$ & MTB \\
\hline & & $\mathrm{C} 13$ & $\mathrm{~TB}$ \\
\hline & & $\mathrm{C} 14$ & LTB \\
\hline
\end{tabular}

The five priority technical characteristics are then used as a reference in making alternative concepts. This priority setting is based on several technical characteristics that have not reached the target yet.

There are 3 types of concepts formed including the existing concept, the concept of benchmarking and the concept of development and innovation as illustrated in Table 11.

These concepts are determined by discussing with the PT. $\mathrm{XYZ}$ website development team, external website developer and some reference sources such as books, articles, journals and competitor's website concepts. The next step, give value to the concepts that have been determined based on
Table 14.

FQFD Iteration 2 (Technical Matrix)

\begin{tabular}{|c|c|c|c|c|}
\hline $\begin{array}{l}\mathbf{N} \\
\mathbf{0}\end{array}$ & $\begin{array}{c}\text { Technical } \\
\text { Characteristics }\end{array}$ & Unit & $\begin{array}{c}\text { Eksistin } \\
\text { g }\end{array}$ & $\begin{array}{c}\text { Targe } \\
t\end{array}$ \\
\hline 1 & SEO article & Article & 0 & 6 \\
\hline 2 & Meta description & Element & 0 & 6 \\
\hline 3 & Meta keywords & Element & 0 & 12 \\
\hline 4 & $\begin{array}{l}\text { Number of clicks on } \\
\text { product selection }\end{array}$ & Click & 2 & 1 \\
\hline 5 & $\begin{array}{l}\text { Number of clicks on } \\
\text { payment }\end{array}$ & Click & 3 & 3 \\
\hline 6 & $\begin{array}{l}\text { Number of clicks on } \\
\text { account creation }\end{array}$ & Click & 1 & 1 \\
\hline 7 & $\begin{array}{l}\text { Number of sticky } \\
\text { menu icons }\end{array}$ & Element & 4 & 1 \\
\hline 8 & $\begin{array}{l}\text { The number of layouts } \\
\text { on the home display }\end{array}$ & Layout & 7 & 8 \\
\hline 9 & $\begin{array}{l}\text { The number of layouts } \\
\text { on the product display }\end{array}$ & Layout & 4 & 4 \\
\hline 10 & $\begin{array}{l}\text { Number of layouts on } \\
\text { payment }\end{array}$ & Layout & 3 & 3 \\
\hline 11 & $\begin{array}{l}\text { Search } \\
\text { recommendation }\end{array}$ & Element & 0 & 7 \\
\hline 12 & Search autocorrect & Element & 0 & 2 \\
\hline 13 & Animated image & Element & 20 & 11 \\
\hline 14 & $\begin{array}{l}\text { The number of pictures } \\
\text { on the home menu }\end{array}$ & Element & 20 & 20 \\
\hline
\end{tabular}

discussions with internal parties on the PT. XYZ website developer. The decision matrix can be seen in Table 12 .

Based on table 12, it can be seen that the chosen concept is the concept of development and innovation to be developed further because it has the highest ranking compared to other concepts. The selected concept is then identified to produce critical parts in the Iteration 2 FQFD which can be seen in Figure 5.

The planning matrix contains column weight percentage values for each technical characteristic that has not yet reached the company's target. This value is obtained based on the results of data processing in Fuzzy QFD iteration one (HOQ). The results of the data in the HOQ will be used as a reference in determining the value of the relationship between technical characteristics and critical parts contained in the iteration QFD matrix relationship (part deployment).

Critical parts are obtained through brainstorming with the PT. XYZ website developer and external website developer. Next, the coding of critical parts is carried out, and the direction of goodness or improvement to be achieved by the company is determined. The determination of direction of goodness is also done by discussing with the PT. XYZ website developer and the external website developer.

Critical part priorities are based on targets that have not been met. Table 14 shows the critical parts used in the prep Critical parts that are prioritized are SEO articles, meta description, meta keywords, number of clicks on product selection, number of sticky menu icons, number of layouts on the home display, search recommendations, search autocorrect, and animated images.aration of recommendations.

\section{CONCLUSION}

In this study, it can be concluded that five priority technical characteristics were produced from thirteen technical 
February $1^{\text {st }} 2020$, Institut Teknologi Sepuluh Nopember, Surabaya, Indonesia

characteristics. Then, after processing using fuzzy QFD second iterations based on the chosen concept in concept development, nine priority critical parts were obtained from fourteen critical parts. The quality development of the PT. $\mathrm{XYZ}$ website is done by giving final recommendations in order to achieve the specified targets based on the result of data processing.

\section{REFERENCES}

[1]. Alsaadi, M. R., Ahmad, S. Z., \& Hussain, M. (2018). A quality function deployment strategy for improving mobile-government service quality in the Gulf cooperation council countries. Benchmarking, 25(8), 3276-3295. https://doi.org/10.1108/BIJ-122017-0333

[2]. Asadabadi, M. R. (2016). A Markovian-QFD Approach in Addressing the Changing Priorities in Customer Needs.

[3]. Deekshith, D., \& Kinslin, D. (2016). A study on digital marketing and its impact. Journal of Chemical and Pharmaceutical Sciences, 9(4), 2059-2062.

[4]. Erdil, N. O., \& Arani, O. M. (2018). Quality function deployment: more than a design tool. https://doi.org/10.1108/IJQSS-02-2018-0008

[5]. Iqbal, Z., Grigg, N. P., Govindaraju, K., \& Campbell-Allen, N. M. (2015). Enhancing prioritisation of technical attributes in quality function deployment. International Journal of Productivity and Performance Management, 64(3), 398-415. https://doi.org/10.1108/IJPPM-10-2014-0156

[6]. Mohanraj, R., \& Sakthivel, M. (2014). A framework for VSM integrated with Fuzzy QFD. https://doi.org/10.1108/TQM-11-20120088

[7]. Nawar, E. A., Backar, S. H., \& El-dardiry, M. A. (2018). Case Study on Fuzzy Blitz Quality Function Deployment. https://doi.org/10.21625/archive.v2i3.366

[8]. Pandiya, R., Wahyudin, A., \& Nareswari, S. P. (2016). Penentuan Skala Prioritas Regulasi Tarif Interkoneksi Menggunakan Metode Fuzzy QFD - TOPSIS Determining Priority Scale of Interconnection Tariff Regulation Using Fuzzy QFD - TOPSIS, 1(1), 77-88.

[9]. Rahatesa, Ridho. (2019). Perancangan Atribut Kebutuhan pada Layanan Situs Web Penjualan "PT. XYZ" Menggunakan Integrasi Fuzzy-Web Quality Dan Model Fuzzy-Refined Kano.

[10]. Rahmana, Arief et al. (2014). Integration of Servqual and Kano Model Into QFD To Improve Quality of Simulation-Based Training on Project Management. International Journal of Basic and Applied Science, 2(3), 59-72.

[11]. Zadeh, L. A. (2015). Fuzzy logic - a personal perspective. Fuzzy Sets and Systems, 1, 1-17. https://doi.org/10.1016/j.fss.2015.05.009 